ancient writings and glyphs literally and in terms of our present-day ideas, hypotheses and preconceptions.

Tentative theories and schools of thought are multiplying owing to the complexities revealed in recent years by researches in all departments. In a valuable summary of current opinions on the origin of species", Prof. J. Ritehie referred to "the minimum that different types of mind are prepared to allow in order to bridge the gulf of scientific analysis". It is evident that the synthetic function of the mind will not give birth to a new synthetic generalisation just yet; but the wider the search for an embryonic hypothesis the sooner will one be found that is workable and acceptable to the majority.

Evolution is a fundamental cosmic principle in all ancient philosophies; but it is conceived as a dual process of involution and evolution operating in spiral cycles. The creative energies of Nature are serial emanations or 'rays' symbolised by numbers, glyphs and geometrical ideographs. While the explanation of the evolution of species (cf. the Purānas and Vedas) is similar to the Darwinian theory of Western science, that given for the origin of man is different.

In "The Descent of Man"3 there is a passage on hermaphrodite forms which shows how near Darwin came to postulating a primeval androgynous stem from which, according to ancient teachings, the mammals sprang.

Briefly, in the Eastern Aryan philosophy :

(1) Each genus has its own 'primordial' and distinctive 'form'; and these ethereal prototypes are gradually precipitated contemporaneously with the condensation of the globe.

(2) They had become semi-physical colloidal forms of bi-sexual animals in the early Secondary Age, and were fully consolidated physiologically, and sexually differentiated during the Jurassic period. Man preceded most of the mammals.

(3) The evolution of species, races and variations was subsequent to the complete physicalisation of the tenuous colloidal forms.

This 'hypothesis', of course, "simply pushes the problem back to"-- another state! But the phenomena of 'periodical precipitation' and of colloidal states had not been investigated in Darwin's time. To-day we are accustomed to seek for 'causes' and 'origins' in imperceptible states.

1 NATURE, 135, 987, Tune 15, 1935.

W. W. L.

2 NATURE, 132, 506, Sept. 30, 1933.

"The Descent of Man", second edition, p. 161.

\section{Alchemy and Music}

THE supposed connexion between alchemy and music is much older than the sources quoted by Prof. Read". A treatise in the "Collection" of Greek alchemists ${ }^{2}$ deals obscurely with this subject, and it has been the object of an interesting study by Prof. Stephanides, of Athens ${ }^{3}$. The ultimate source is, of course, the "Timaeus" of Plato, in which the compositions of materials are explained as due to mysterious 'harmonies'. Plato was in later life much influenced by Pythagorean schools, as has been shown by Frank". He was obsessed by the idea that mathematics is in some way or other the ultimate reality, and that Nature must be explained by mathematical laws, or even Nature is these mathematical laws. In this he seems surprisingly 'modern', or rather, modern views seem surprisingly Platonic.
Most of the ideas of later alchemy are merely more or less denatured versions of the theories of the Greek alchemists, and if the music was intended for per. formance during the practical operations this may also be an old ritual.

Wembley.

\section{J. R. Partington.}

1 NATURE, 135, $967 ; 1935$.

Berthelot, "Collection des Alchimistes Grecs", 2, 421.

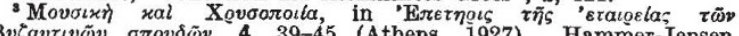

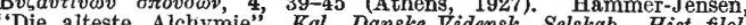
Die alteste Alchymie", Kgl. Danske Vidensk. Selskab., Hist.-filol. Meddel., 4, ii, 144 (1921) - 's

"'Plato und die sogennanten Pythagoreer", Halle, 1923.

THE lecture concerned dealt exclusively with certain aspects of seventeenth century alchemy, and Maier's musical compositions of 1618 may perhaps be taken as the last and most definite attempt to associate alchemy with music. Prof. Partington's early references are very interesting.

St. Andrews.

JOHN READ.

\section{Breeding of Loris in Captivity}

THERE is no record of Loris having been bred in captivity, so it seems worth recording that one was born in my collection recently.

This animal is well known to be difficult to keep alive in confinement, and in the hands of most persons who have kept them they live only two to three months. As the period of gestation appears to be longer than this, it is not surprising that breeding has not occurred, though several instances have been recorded $^{1}$ of babies having been born to females already pregnant at the time of their capture.

Upwards of fifty individuals of the genus have now passed through my hands, and I have been successful in keeping them alive in confinement for varying periods. Some still alive have been in captivity for more than two years. The Mysore loris (L. tardigradus lydekkerianus) appears to stand confinement better than the Ceylonese races.

In April 1934, on leaving Ceylon on furlough, I left my collection in the charge of Dr. L. Nicholls, Government bacteriologist. In one cage were a number of specimens of the loris $L$. t. tardigradus, and in the same month was added a full-grown male of the northern race, $L$. $t$. nordicus. I noticed that, at the time of handing over, all the males had their testes fully descended, whereas previously their scrota had been empty. The descent in some of the males took place over-night.

All the lowland lorises in the cage mentioned died in my absence, except one female. She was evidently impregnated by the northern male in the latter part of 1934. Dr. Nicholls informs me that no copulation was observed. A baby was born on April 24, 1935. I noticed a few days later that the father had his testes descended again.

It seems out of the question for the pregnancy to have occurred as a result of the rutting activities of the male in April 1934, as this would give a pregnancy of nearly a year. It seems much more likely that the male has a testicular descent twice a year as suggested by Narayan $\mathrm{Rao}^{2}$, and that the pregnancy dated from a rutting season in or about September or October 1934.

Although the full evidence cannot be discussed here, it would seem that Loris in its breeding habits 